\title{
SHELLEY'S SOPHOCLES.
}

Unter dem titel 'Aeschylus or Sophocles' bringt Mr. Horace S. Fiske ') in der New York Nation March 28. 1901 (p. 252 c) eine urkundliche bestätigung des bereits von Dowden Life of Shelley 2, 529 berichtigten irrtums von Trelawny's Recollections (1858). Nach Trelawny's Recoll. [und daraus in Garnett's Shelley's Last Days übergegangen ${ }^{2}$ )] war ein band Aeschylos 'in one pocket' und Keats 'in the other' ein beweis, dass es sich um die leiche Shelley's handelte, wie sie in der Bai von Spezia ans ufer geschwemmt wurde. Der name 'Aeschylos' war in Trelawny's Records 1878 stillschweigend in ' $\mathrm{So}$ phocles' verwandelt, und Dowden a. a. 0. giebt philologisch genau die berichtigung. Jetzt hat prof. W. R. Morfill zu Oxford in der oben citierten nummer der Nation, die nicht allen deutschen Shelleyforschern zugänglich sein dürfte, den endgiltigen beweis, dass es sich um einen Sophocles handelt, mitgeteilt:

"The evidence comes from Lady Shelley the poet's daughter-in-law, and may be relied upon. The book is a copy of Sophocles, Oxford edition, 1809, two volumes bound in one. It is true that Shelley held it in his hand, ${ }^{3}$ ) and was clasping it when his body was found. This is attested in documents under the hand of Lady Shelley, and they are bound up in a volume as pièces justificatives."

1) Verfasser eines sonetts: To Shelley's Sophocles.

2) Von Garnett übrigens berichtigt in seinem artikel Shelley im Dict. Nat. Biogr.

s) Garnett DNB.: 'recognised by the volumes of Sophocles and Keats in his pockets'.

E. FlüGeL. 